\title{
OPEN Removal behaviour of residual pollutants from biologically treated palm oil mill effluent by Pennisetum purpureum in constructed wetland
}

Farhana Aziz Ujang ${ }^{1}$, Ahmad Muhaimin Roslan ${ }^{1 凶}$, Nurul Atiqah Osman ${ }^{1}$, Ashreen Norman ${ }^{1}$, Juferi Idris ${ }^{2}$, Mohammed Abdillah Ahmad Farid ${ }^{1}$, Mohd Izuan Effendi Halmi ${ }^{3}$, Misri Gozan ${ }^{4}$ \& Mohd Ali Hassan ${ }^{1}$

The reason for such enormous efforts in palm oil mill effluent research would be what has been singled out as one of the major sources of pollution in Malaysia, and perhaps the most costly and complex waste to manage. Palm oil mill final discharge, which is the treated effluent, will usually be discharged to nearby land or river since it has been the least costly way to dispose of. Irrefutably, the quality level of the treated effluent does not always satisfy the surface water quality in conformity to physicochemical characteristics. To work on improving the treated effluent quality, a vertical surface-flow constructed wetland system was designed with Pennisetum purpureum (Napier grass) planted on the wetland floor. The system effectively reduced the level of chemical oxygen demand by $62.2 \pm 14.3 \%$, total suspended solid by $88.1 \pm 13.3 \%$, ammonia by $62.3 \pm 24.8 \%$, colour by $66.6 \pm 13.19 \%$, and tannin and lignin by $57.5 \pm 22.3 \%$. Heat map depicted bacterial diversity and relative abundance in life stages from the wetland soil, whereby bacterial community associated with the pollutant removal was found to be from the families Anaerolineaceae and Nitrosomonadaceae, and phyla Cyanobacteria and Acidobacteria.

In Malaysia, palm oil is known as the largest agriculture sector, contributing considerably to the country's economic growth ${ }^{1}$. The oil palm plantation area accounts for $11 \%$ of Malaysian land ${ }^{2}$ and produces over 13 million tonnes of crude palm oil each year ${ }^{3}$. Nevertheless, huge growth entails negative externalities, especially towards the environment. Palm oil mill effluent (POME) has been identified to be one of the major sources of water pollution due to its high biochemical oxygen demand (BOD) and chemical oxygen demand (COD) concentrations ${ }^{4}$. As a result, POME is considered as the most costly and crucial waste to be managed, mainly due to its huge volume $^{5-7}$. Although POME is non-hazardous, it still poses an ecological threat to the aquatic lives due to the immense oxygen consumption capacity in the photo-oxidation of its high organic compounds. Presently, palm oil mills in Malaysia are treating their POME into final discharge (POME FD) using a ponding system due to its low cost and ability to effectively reduce the generated pollutants. POME FD would typically be released to neighbouring waterways as it is the least expensive disposal practice ${ }^{5}$ even though it hardly met the minimum discharge limits for river quality by retaining comparatively high suspended solids (SS) and COD ${ }^{8}$. Table 1 shows that POME FD released still contained high amount of SS and COD value as compared to Malaysia Standard Discharge Limit. Therefore, the best way to resolve this issue is by proposing an additional polishing treatment to further reduce the contamination level prior to discharge 9 .

To further remove the residual pollutants from POME FD, the use of green plants along with proper soil amendment such as phytoremediation in a constructed wetland (CW) can be applied. Pollutants are innately degraded, removed or immobilised during phytoremediation, where the process costs way less, and with low carbon footprint as compared to other techniques, e.g. adsorbent, bioreactors, or convective drying, in treating a sizeable volume of $\mathrm{POME}^{10,11}$. As an engineered wetland, $\mathrm{CW}$ can be designed to mimic the natural wetlands to

\footnotetext{
${ }^{1}$ Department of Bioprocess Technology, Faculty of Biotechnology and Biomolecular Sciences, Universiti Putra Malaysia (UPM), 43400 UPM Serdang, Selangor, Malaysia. ${ }^{2}$ Faculty of Chemical Engineering, College of Engineering, Universiti Teknologi MARA (UiTM), Sarawak Branch, Samarahan Campus, 94300 Kota Samarahan, Sarawak, Malaysia. ${ }^{3}$ Department of Soil Management, Faculty of Agriculture, Universiti Putra Malaysia (UPM), 43400 UPM Serdang, Selangor, Malaysia. "Department of Chemical Engineering, Faculty of Engineering, Universitas Indonesia, Kampus Baru UI, Depok, Jawa Barat 16424, Indonesia. ${ }^{凶}$ email: ar_muhaimin@upm.edu.my
} 


\begin{tabular}{|l|l|l|l|}
\hline Parameters & Final discharge $^{9}$ & Final discharge $^{8}$ & Standard $^{\mathrm{a}}$ \\
\hline $\mathrm{BOD}_{5}(\mathrm{mg} / \mathrm{L})$ & 65 & $\mathrm{NM}$ & 20 \\
\hline $\mathrm{COD}(\mathrm{mg} / \mathrm{L})$ & 520 & 395 & 80 \\
\hline $\mathrm{TSS}(\mathrm{mg} / \mathrm{L})$ & 217 & 117 & 50 \\
\hline $\mathrm{NH}_{4}{ }^{+}-\mathrm{N}(\mathrm{mg} / \mathrm{L})$ & $\mathrm{NM}$ & $\mathrm{NM}$ & 10 \\
\hline Colour $(\mathrm{Pt}-\mathrm{Co})$ & $\mathrm{NM}$ & $\mathrm{NM}$ & - \\
\hline $\mathrm{pH}$ & 8.50 & 9.3 & $6.0-9.0$ \\
\hline
\end{tabular}

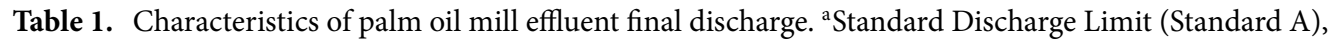
Department of Environment (DOE), Malaysia. NM not measured.

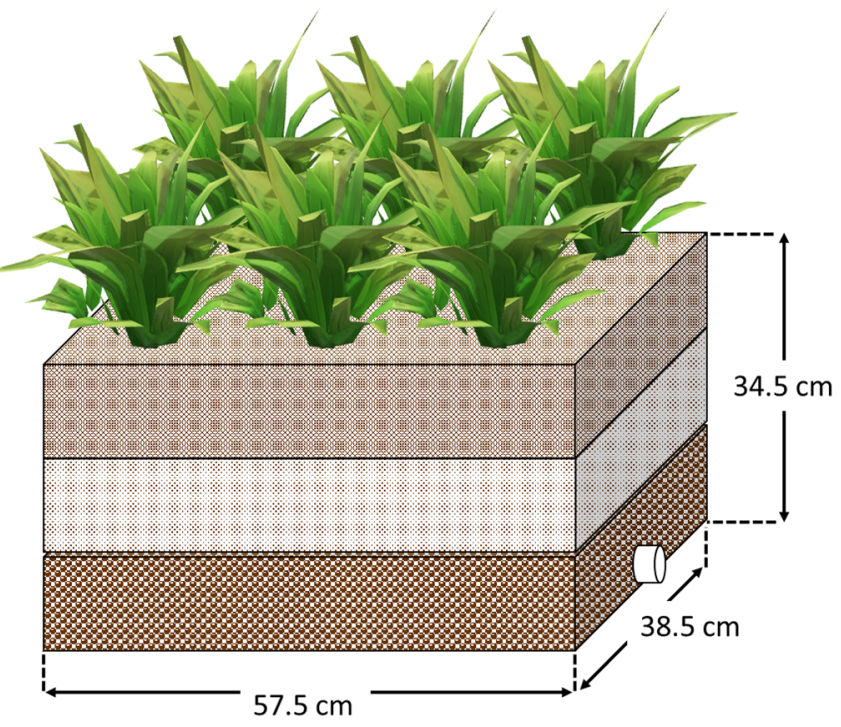

Figure 1. Design of the constructed wetland system.

treat wastewater ${ }^{12}$. Vegetation on the $\mathrm{CW}$ will induce the growth of soil microorganisms, and foster an ecosystem surrounding the roots, primarily to remove and immobilise contaminants from the wastewater. The resulted wastewater with lesser residual pollutants is important, because it will have lower impact to the receiving water body, as compared to wastewater without CW. Several plants have been studied to effectively remove pollutants from the environment through several methods of phytoremediation such as rhizodegradation, phytoimmobilisation, phytoextraction, phytodegradation, phytofiltration, phytostabilisation, phytodesalination, and phytovolatilisation ${ }^{13}$. Pennisetum purpureum (Napier grass) is one of the plant species used for the remediation of industrial and agricultural effluents due to its rapid growth rate and ability to survive in highly contaminated soil. A study has also reported that $P$. purpureum has the potential to absorb significant amount of excess nutrients in wastewater ${ }^{14}$. Furthermore, soil microorganisms in CW have also been proven to associate in pollutant removal such as nitrogen ${ }^{15}$, organic matters ${ }^{16}$, industrial organic pollutants ${ }^{17}$, and emerging organic contaminants ${ }^{18,19}$, either as free-floating microorganisms in interstitial water, as well as bound to CW substrates and plant roots ${ }^{20}$.

Since the POME FD contains a lot of residual organic pollutants, which can become nutrients for plants such as $P$. purpureum growth, it is important to understand the removal behaviour of these residual pollutants in $\mathrm{CW}$, and the shifting of microorganism community associated with the process. Although previous studies have analysed independent water samples ${ }^{21,22}$ as well as substrate samples ${ }^{23,24}$ to understand the microbial characteristics in CW, the study on removal behaviour of residual pollutants in POME FD using CW is still lacking. The objective of this study is to understand the removal behaviour of pollutants from POME FD in a CW using P. purpureum to achieve the receiving river water quality. A bacterial community study was also conducted to further understand the relationship between the microorganisms and pollutants removal.

\section{Materials and methods}

Experimental designs. The constructed wetland system was set up according to Fig. 1 in triplicate for every study, in a greenhouse. Every tank used to create the wetland has a working capacity of $60 \mathrm{~L}$, measuring approximately $40.5 \mathrm{~cm}$ high, $57.5 \mathrm{~cm}$ long, and $38.5 \mathrm{~cm}$ wide. The tanks were filled with three types of media or substrate for plant cultivation and wastewater treatment. From the bottom, $11.5 \mathrm{~cm}$ height of stones with $3-5 \mathrm{~cm}$ diameter was lined as the first layer. The second layer was filled with coarse sands with $11.5 \mathrm{~cm}$ height, while the third layer was $11.5 \mathrm{~cm}$ height of fine sands. Each medium has its function; stone or gravel in the bottom 


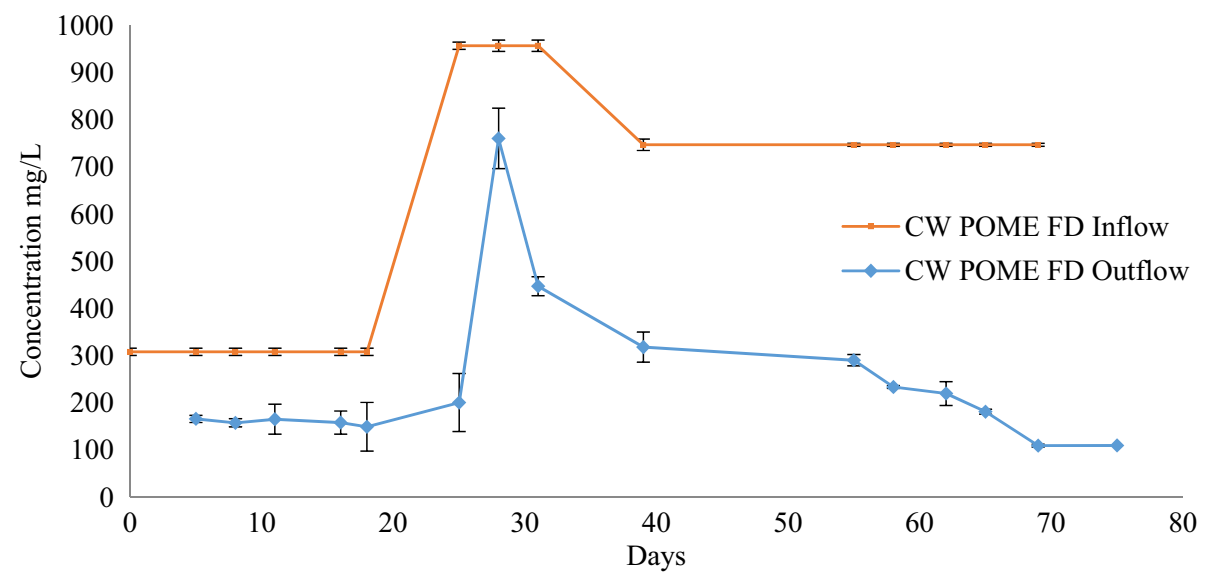

Figure 2. The chemical oxygen demand (COD) reduction profile after the treatment using constructed wetland system for 75 days.

layer serves as the supporting layer, coarse sand in the second layer is the main substrate layer, and the fine sand in the upper layer facilitates the dispersion of wastewater and growth of plants. At the bottom of the CW, and outlet pipe (diameter $2.5 \mathrm{~cm}$ ) is installed to collect the effluent sample. P. purpureum (common cultivar) used in this study was obtained with permission from Biomass Technology Laboratory, Universiti Putra Malaysia, and was used and maintained within the facility. It was grown for 2 months prior to transplanting into three wetland tanks that were designated for this experiment.

Experimental procedure. The sample of POME FD used in this study was collected from a palm oil mill located in Felda Pasoh, Negeri Sembilan. The FD was retrieved from the final processing line of the POME treatment system within the POME biopolishing plant, and immediately collected as the effluent flew into the drain. The effluent samples were then kept at $4{ }^{\circ} \mathrm{C}$ before use.

The wetlands were supplemented with $5 \mathrm{~L}$ of POME FD on daily basis. The effluent from each tank was channelled through a drainpipe $(2.5 \mathrm{~cm}$ diameter $)$ at the bottom of the tank, which was then collected for analysis purposes. The sampling was done periodically every three days from each tank for 75 days of treatment. Following sampling, the influent and effluent samples from the CW were then immediately analysed for COD, TSS, ammonium nitrogen $\left(\mathrm{NH}_{4}{ }^{+} \mathrm{N}\right)$, colour, and tannin and lignin, according to Standard Methods for the Examination of Water and Wastewater ${ }^{25}$. These samples were also analysed for heavy metals by inductively coupled plasma mass spectrometry (ICP-MS).

Plant physiology. The measurement for P. purpureum growth was performed once per week. The measurement was also taken before the experiment, and on the last day of treatment.

Microbial analysis. Sediments from three different points in each CW were collected before combined into a single composite sample. The sediments and the mixed liquors were extracted with a DNA extraction kit from MOBIO PowerSoil to recover complete genomic DNA, and preserved at $-20^{\circ} \mathrm{C}$. The sample was then proceeded with a high-throughput MiSeq Illumina sequencing platform to analyse the influence of the POME FD and wetland effluent on the bacterial community composition. The preserved DNA was sent to Biolution Resources, Ampang, Selangor, Malaysia, where the sequencing was conducted on the 16S rRNA gene in the V3 and V4 regions. The taxonomy of each $16 \mathrm{~S}$ rRNA gene sequence was analysed by RDP Classifier against the Silva (SSU123) 16S rRNA database using a confidence threshold of 0.7. The number of all OTU in rarefaction curve was in the saturation phase, indicating that OUTs have been sufficiently recovered in the sequencing. The result from Biolution Resources were then imported and analysed in Microsoft Excel spreadsheet with pivot tables. This table was analysed to create a heatmap using the relative abundance of each genus. The colours on the heatmap represent the relative abundance. For each row, the rule applied identified the highest (red) and the lowest (green) values, and assigned colour gradient for the values in between.

\section{Results and discussion}

Removal of COD in constructed wetland. The CW had a steady state of outflow values after 75 days of operation, and good plant growth was observed. The system started to release effluent on the third day after the first influent was added. COD in the effluent was in adaptation process in the beginning because microorganisms and plants had not adapted and matured in the conditions provided by the FD ${ }^{26}$. Generally, the COD removal efficiencies in wetlands were $88.4 \pm 0.24 \%$ at day 75 . COD concentration gradually decreased with time from day 27 to 75 as shown in Fig. 2. COD concentration showed a continuous reduction as compared to the input. Although a higher COD concentration of POME FD was supplied at day 24, the CW managed to reduce it by $15.84 \pm 0.22 \%$ at day 28 . 


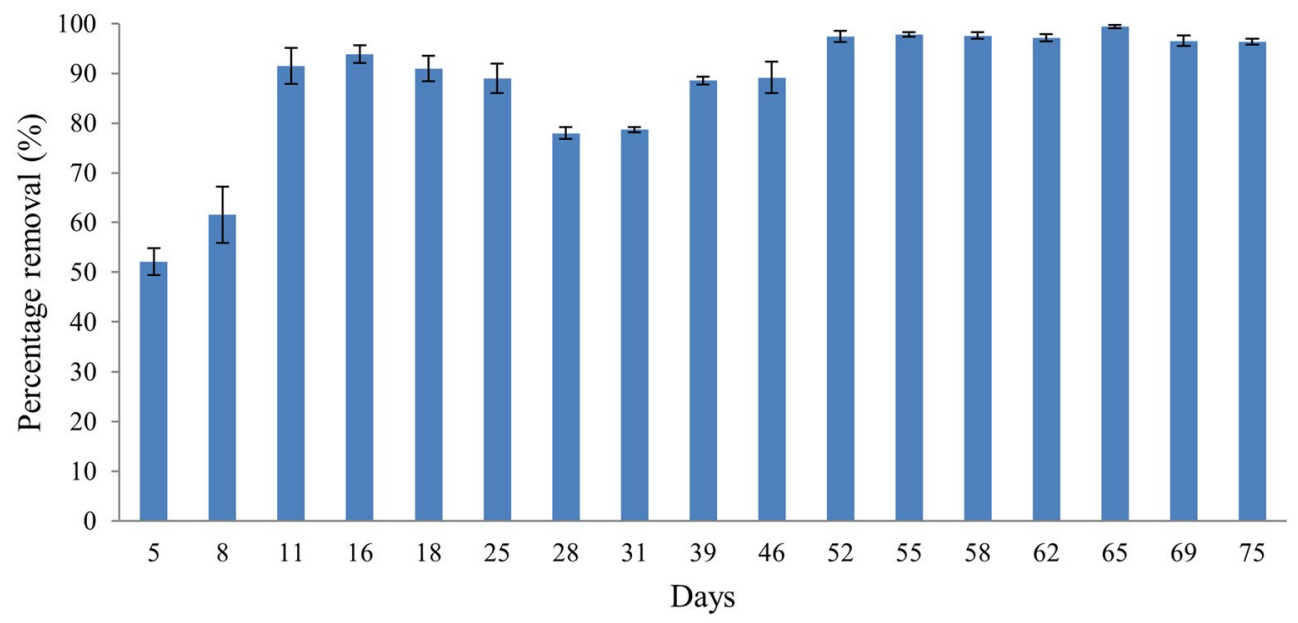

Figure 3. The total suspended solids (TSS) reduction profile after the treatment using constructed wetland system for 75 days.

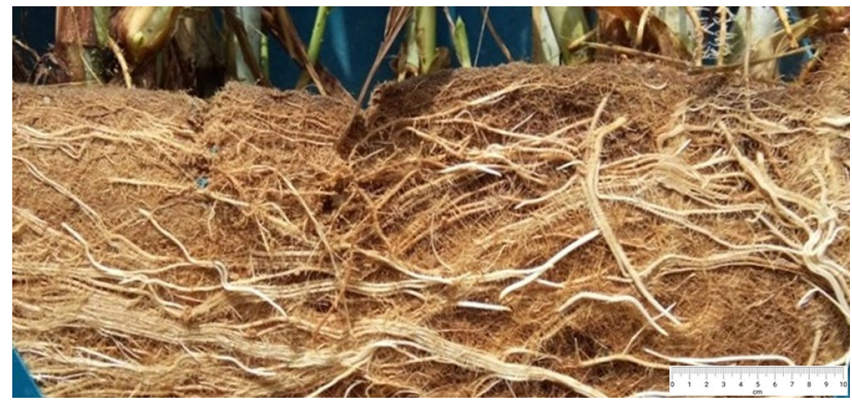

Figure 4. The root of $P$. purpureum in the constructed wetland at day 75 .

The concentration of influent had an effect on the elimination of COD. The removal of COD can be explained by the function of the P. purpureum in the CW as the plant roots exuded additional organic matters ${ }^{27}$, which led to the changes of COD concentration. After 27 days, the living roots had flourished and became sturdier, which had stimulatory effect on soil organic matter decomposition, thus indicating development of roots-induced microbiota ${ }^{28,29}$. On top of that, the microbial communities within the $\mathrm{CW}$ ecosystem were seeded by the presence of bacteria in the POME FD that were involved in anaerobic digestion. One of the major bacterial constituents that can be found in the POME FD was Pseudomonas sp. This bacterium is capable of dye degradation or colour removal, biodegradation of hydrocarbon, and insecticide degradation such as Malathion ${ }^{30,31}$. It has been reported that Pseudomonas aeruginosa is capable to reduce the COD level from POME in a microbial fuel cell ${ }^{32}$, as well as the COD level of urban wastewater ${ }^{33}$.

Removal of total suspended solid in constructed wetland. Figure 3 shows the removal of TSS from POME FD. Different concentrations of POME FD were supplied throughout this study to simulate a real palm oil mill. Even though the wastewater input into the wetland did not have the same initial TSS concentration, the system still managed to reduce the TSS up to $88.1 \pm 13.3 \%$. The POME FD concentrations supplied were $129 \pm 3.2 \mathrm{mg} / \mathrm{L}$ (day 0-24), $295 \pm 4.3 \mathrm{mg} / \mathrm{L}$ (day 27-39) and 553.7 $\pm 11.2 \mathrm{mg} / \mathrm{L}$ (day 46-72). The concentrations of TSS from the CW outlet for day 25 , day 46 , and day 75 were $13.6 \pm 3.6 \mathrm{mg} / \mathrm{L}, 30.2 \pm 8.5 \mathrm{mg} / \mathrm{L}$, and $19.4 \pm 3.3 \mathrm{mg} / \mathrm{L}$, respectively.

Dhulap and Patil ${ }^{34}$ have shown the potential of $P$. purpureum to minimise TSS in sewage by $55.17 \%$. The removal strategies for TSS in CW are via sedimentation and filtration. Particulates were removed whenever the POME FD seeped through the developed root masses of $P$. purpureum, gravel, and sand. This finding matches current finding as the sedimentation of the solids happened at the top of the $\mathrm{CW}$, and the roots of $P$. purpureum also showed massive growth in the entire $\mathrm{CW}$, as shown in Fig. 4. Typically, the CW has a lengthy hydraulic retention time, often several days, to extract settle-able and floatable solids while bacterial growth and interactions with adsorbed species remove non-settling solids.

Removal of tannin and lignin in constructed wetland. Tannins, also known as polyphenols, are by far the most abundant macromolecules contained in POME that greatly affect its colour, and create musty odour ${ }^{35}$. 


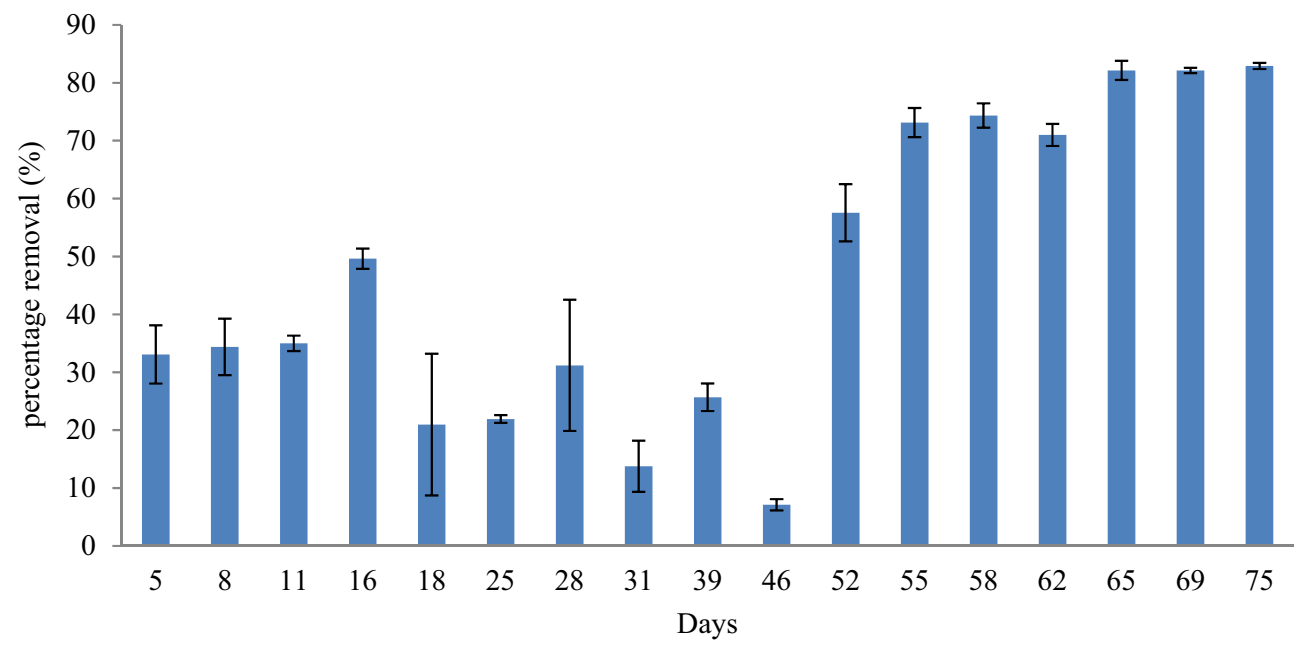

Figure 5. The tannin and lignin reduction profile after the treatment using constructed wetland system for 75 days.

The tannins leaching onto the run-off wastewater from the palm oil processing give the brown colouring effect to the POME. From the results obtained, tannin and lignin concentrations were decreasing in three phases as the inlet of the CW was taken in different batches for three consecutive months at Felda Pasoh, Negeri Sembilan.

Overall, the tannin and lignin contents decreased from the initial concentration as shown in Fig. 5. The concentrations of tannin and lignin in the inlet of CW were $8.7 \pm 0.6 \mathrm{mg} / \mathrm{L}, 14.5 \pm 0.2 \mathrm{mg} / \mathrm{L}$, and $21.8 \pm 0.4 \mathrm{mg} / \mathrm{L}$. The removal of tannin and lignin was showing as early as day 3 , which then reduced to $6.4 \pm 0.9 \mathrm{mg} / \mathrm{L}$ and $4.5 \pm 0.6 \mathrm{mg} / \mathrm{L}$ at day 15 . The concentration drastically increased on day 27 due to the high concentration of the inlet of CW. Overall, the removal of tannin and lignin was $57.5 \pm 22.3 \%$ using this $\mathrm{CW}$, and believed to be related to the loading rates and hydraulic retention time (HRT). According to Grismer and Sherpherd ${ }^{36}$, a smaller loading rate and greater HRT can influence the removal efficiency to reach nearly $100 \%$ provided that the recirculation system of effluent is applied. It was reported that CW have been proven to have the ability to reduce the concentration of tannin and lignin in wood waste leachate ${ }^{37}$. The study reported that there was a total reduction of $42 \%$ of tannin and lignin using the CW planted with a cattail (Typha sp.). This is in agreement with Grismer and Sherpherd ${ }^{36}$ who reported successful reduction of up to $77.9 \%$ of tannin and lignin from the winery process wastewater by subsurface flow wetland. Comparing both studies with this study, better removal of tannin and lignin was achieved on day 52 to day 75 of $82.9 \pm 0.47 \%$, which is higher than reported literature ${ }^{36,37}$.

Removal of effluent colour in constructed wetland. The colour of wastewater is one of the parameters that must be treated. A high concentration of colour in wastewater has an impact on the environment by reducing the penetration of sunlight into the water body, and this is often caused by organic matters which include suspended and dissolved particles. Dissolved organic matters, such as humus, peat, and plant decay contribute to the yellow or brown colour of the wastewater, whereas as the dissolved organic acids including tannin and lignin give the wastewater a tea colour. According to Mohammed and Chong ${ }^{35}$, there is a correlation between TSS, and tannin and lignin contents of POME, and the resulting effluent colour.

By reducing the concentration of TSS, and tannin and lignin in the POME FD, the colour concentration may also decrease. In this study, the colour started to reduce from day 3 to day 75 . The colour concentration in this study is represented by platinum-cobalt (Pt-Co). Initially, the colour of POME FD recorded was $493 \pm 3 \mathrm{Pt}-\mathrm{Co}$ (day 0-24), $1330 \pm 31 \mathrm{Pt}-\mathrm{Co}$ (day 27-39), and $2501 \pm 47 \mathrm{Pt}-\mathrm{Co}$ (day 46-75). Based on Fig. 6, the colour of treated POME FD reduced to $310 \pm 16 \mathrm{Pt}-\mathrm{Co}$ (day 24), to $491 \pm 16 \mathrm{Pt}-\mathrm{Co}$ (day 45), and finally to $238 \pm 4 \mathrm{Pt}-\mathrm{Co}$ (day 75).

Overall, the CW managed to yield $57.5 \pm 22.3 \%$ of colour removal, thus indicating the effectiveness of using $P$. purpureum in removing the colour ${ }^{34}$. It is expected that the dissolved solids that add to the colour will be washed out by the CW. The presence of bacteria in the CW often also leads to a decrease in colour quality ${ }^{32}$.

Removal of ammonium nitrogen in constructed wetland. As the concentration of ammonium nitrogen $\left(\mathrm{NH}_{4}{ }^{+}-\mathrm{N}\right)$ was high inside the POME FD $(14.26 \pm 0.04 \mathrm{mg} / \mathrm{L})$, the CW was used to reduce its concentration. Figure 7 exhibits the ammonia removal after 75 days in the CW. The influents of the CW were different at $3.66 \pm 0.01 \mathrm{mg} / \mathrm{L}, 14.26 \pm 0.04 \mathrm{mg} / \mathrm{L}$, and $8.92 \pm 0.04 \mathrm{mg} / \mathrm{L}$ according to the date of sampling for every batch which was in July, August, and September, respectively. An extended HRT would lengthen the contact interval between microorganisms and organic matters in wastewater, thus increasing the efficiency of $\mathrm{NH}_{4}{ }^{+}-\mathrm{N}$, contrary to a shortened HRT which would inadequately remove the ammonia as a result of reduced time for nutrient uptake by the nitrifying bacteria, thereby slowing down the proliferation of autotrophic bacteria ${ }^{38}$.

Even though the initial concentration had higher values, at the end of the treatment, the CW managed to reduce the concentration of $\mathrm{NH}_{4}{ }^{+}-\mathrm{N}$ to $1.4 \pm 0.4 \mathrm{mg} / \mathrm{L}, 3.8 \pm 0.4 \mathrm{mg} / \mathrm{L}$, and $1.2 \pm 0.1 \mathrm{mg} / \mathrm{L}$, of about $64.8 \pm 9.6 \%$, $56.6 \pm 4.6 \%$, and $86.2 \pm 1.7 \%$, respectively. The $\mathrm{NH}_{4}{ }^{+}-\mathrm{N}$ concentrations were only fractionally declined within 


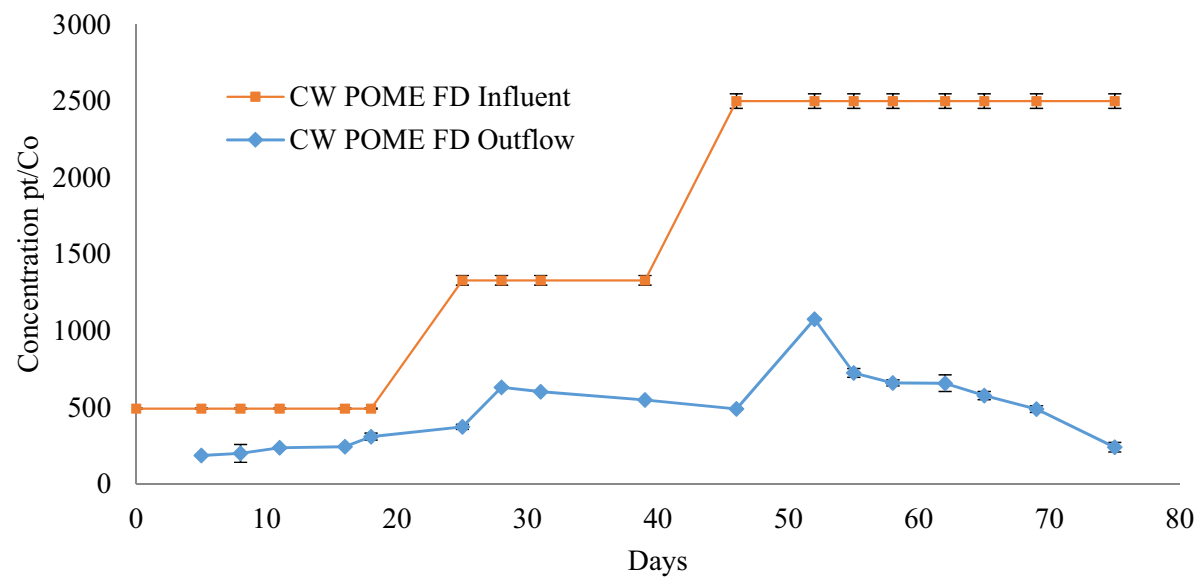

Figure 6. The colour reduction profile after the treatment using constructed wetland system for 75 days.

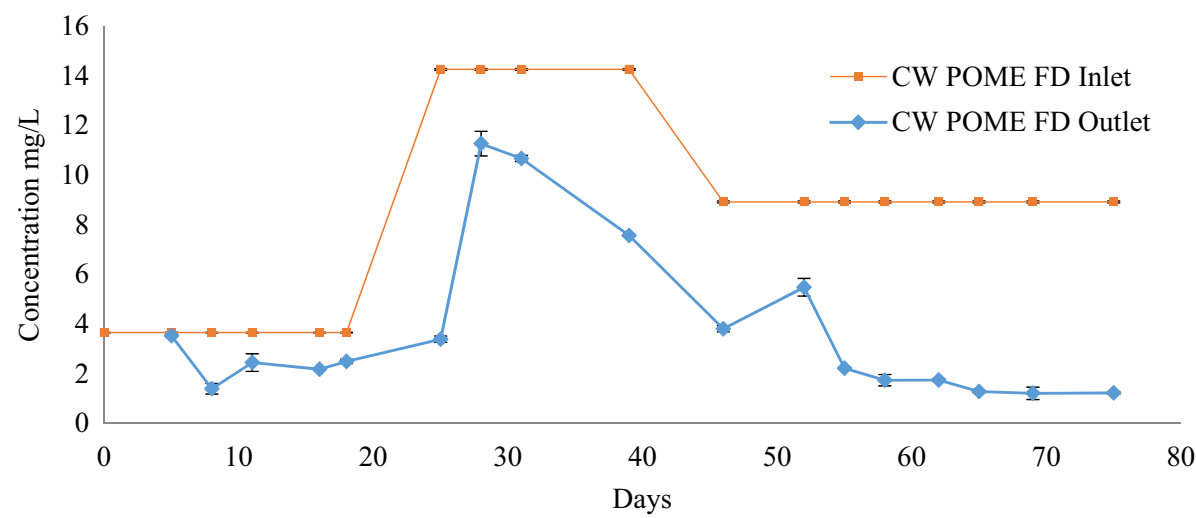

Figure 7. The ammonia reduction profile after the treatment using constructed wetland system for 75 days.

the first few days by $7.3 \pm 0.4 \%$ due to a large amount of dissolved oxygen that has been consumed by the organic matters for degradation. $\mathrm{NH}_{4}{ }^{+}-\mathrm{N}$ concentrations stabilised after 57 days, at $1.7 \pm 0.2 \mathrm{mg} / \mathrm{L}$, and on day 60 at $1.74 \pm 0.04 \mathrm{mg} / \mathrm{L}$. On days 63,66 , and 75, there were stable $\mathrm{NH}_{4}{ }^{+}-\mathrm{N}$ concentrations at $1.3 \pm 0.3 \mathrm{mg} / \mathrm{L}$, $1.2 \pm 0.1 \mathrm{mg} / \mathrm{L}$, and $1.2 \pm 0.1 \mathrm{mg} / \mathrm{L}$, respectively. This suggests that there has been a combination of $\mathrm{NH}_{4}{ }^{+}-\mathrm{N}$ sorption onto CW substrates, microbial assimilation, and nitrification at the air-water interface ${ }^{39} . \mathrm{NH}_{4}^{+}-\mathrm{N}$ concentrations steadily declined as HRT increased, with removal performance recorded at $74.4 \pm 0.4 \%$ and $84.2 \pm 1.8 \%$.

A study has reported the low reduction trend of hydrocarbon in the first 60 days, and greatly decreased towards the end of the experiment once the maturity phase has been achieved ${ }^{40}$. This explains that the removal of $\mathrm{NH}_{4}^{+}-\mathrm{N}$ did not only rely on the adsorption by the $\mathrm{CW}$ substrates, but also on photosynthesis acclamation and root development of the plants, as well as sufficiency of oxygen supply to rhizosphere aerobic microorganisms ${ }^{13}$. In context of biogeochemical nitrogen cycle, there are three oxidative steps involved in converting ammonia to nitrate $\left(\mathrm{NH}_{4}{ }^{+} \rightarrow \mathrm{NH}_{2} \mathrm{OH} \rightarrow \mathrm{NO}_{2}^{-} \rightarrow \mathrm{NO}_{3}^{-}\right)^{41}$. P. purpureum will absorb the nitrates and enhance its growth. In this study, the $\mathrm{CW}$ managed to reduce the concentration of $\mathrm{NH}_{4}{ }^{+}-\mathrm{N}$ in POME FD by $62.3 \pm 24.8 \%$.

Effluent characteristics in the constructed wetland. Overall, the effluent characteristics after being treated in the $\mathrm{CW}$ showed a higher reduction in FD concentration as compared to its initial concentration. Table 2 shows the different initial concentrations of FD in July, August, and September due to the different seasons. In July, the concentration of FD was quite low as compared to the concentrations in August and September since it was a rainy season. Thus, the concentration of the FD was diluted by the rain. On the contrary, August and September were dry seasons, hence the concentrations of FD were quite high. However, even with different initial concentrations, $52.4 \pm 8.2 \%, 66.9 \pm 2.2 \%$, and $85.2 \pm 0.5 \%$ removal of COD was recorded in each three different months. Concentrations of TSS were reduced to $88.9 \pm 2.9 \%, 90.5 \pm 2.7 \%$, and $96.4 \pm 0.6 \%$ in those months, respectively. For the concentration of colour, September showed the highest removal $(90.4 \pm 0.18 \%)$, followed by $63.1 \pm 0.36 \%$ in August. and $50.4 \pm 4.57 \%$ in July. The ammonia concentration also showed an increment in removal in July, August, and September by $31.1 \pm 3.8 \%, 72.9 \pm 3.4 \%$, and $86.2 \pm 1.7 \%$, respectively.

Overall, the CW managed to reduce the concentration of COD, TSS, tannin and lignin, colour, and ammonia in the FD. Approximately $62.2 \pm 14.3 \%, 88.1 \pm 13.3 \%, 57.5 \pm 22.3 \%, 66.6 \pm 13.2 \%$, and $62.3 \pm 24.8 \%$ of COD, TSS, 


\begin{tabular}{|l|c|c|l|c|c|l|r|r|r|}
\hline & \multicolumn{3}{|l|}{ July (1st month) } & \multicolumn{2}{l|}{ August (2nd month) } & \multicolumn{2}{l|}{ September (3rd month) } \\
\cline { 2 - 11 } Parameter & Initial conc. & Final conc. & $\begin{array}{l}\text { Removal } \\
(\%)\end{array}$ & Initial conc. & Final conc. & $\begin{array}{l}\text { Removal } \\
(\%)\end{array}$ & $\begin{array}{l}\text { Initial } \\
\text { conc. }\end{array}$ & Final conc. & $\begin{array}{l}\text { Removal } \\
\text { (\%) }\end{array}$ \\
\hline COD (mg/L) & $308.5 \pm 7.7$ & $149.6 \pm 24.6$ & $52.4 \pm 8.2$ & $957.3 \pm 12.1$ & $318.6 \pm 20.0$ & $66.9 \pm 2.2$ & $747.3 \pm 3.2$ & $109.8 \pm 3.1$ & $85.2 \pm 0.5$ \\
\hline TSS (mg/L) & $129.4 \pm 3.2$ & $13.6 \pm 3.6$ & $88.9 \pm 2.9$ & $295.0 \pm 4.3$ & $30.2 \pm 8.5$ & $90.5 \pm 2.7$ & $553.7 \pm 11.2$ & $19.4 \pm 3.3$ & $96.4 \pm 0.6$ \\
\hline $\begin{array}{l}\text { Tannin and } \\
\text { lignin (mg/L) }\end{array}$ & $8.7 \pm 0.6$ & $4.5 \pm 0.6$ & $50.7 \pm 2.6$ & $14.5 \pm 0.2$ & $9.2 \pm 1.6$ & $25.3 \pm 2.1$ & $21.8 \pm 0.4$ & $3.7 \pm 0.1$ & $83.1 \pm 0.5$ \\
\hline Colour (Pt/Co) & $493 \pm 3.5$ & $244.5 \pm 22.5$ & $50.4 \pm 4.6$ & $1330.8 \pm 31.5$ & $491.3 \pm 4.8$ & $63.1 \pm 0.4$ & $2501 \pm 47.8$ & $238.3 \pm 4.5$ & $90.4 \pm 0.2$ \\
\hline $\mathrm{NH}_{4}{ }^{+}-\mathrm{N}(\mathrm{mg} / \mathrm{L})$ & $3.7 \pm 0.01$ & $2.5 \pm 0.1$ & $31.1 \pm 3.8$ & $14.3 \pm 0.04$ & $3.8 \pm 0.4$ & $72.9 \pm 3.4$ & $8.9 \pm 0.04$ & $1.2 \pm 0.1$ & $86.2 \pm 1.7$ \\
\hline
\end{tabular}

Table 2. The values of initial concentrations of wetland influent and the final concentrations of wetland effluent with the removal percentage in 3 months of continuous treatment process.

\begin{tabular}{|l|l|l|l|l|l|l|l|l|}
\hline COD (\%) & TSS (\%) & $\begin{array}{l}\text { Tannin and } \\
\text { lignin (\%) }\end{array}$ & Colour (\%) & $\mathbf{N H}_{4}{ }^{+}-\mathbf{N}(\%)$ & $\begin{array}{l}\text { Types of } \\
\text { wetland }\end{array}$ & $\begin{array}{l}\text { Types of } \\
\text { wastewater }\end{array}$ & Types of plant & Refs. \\
\hline 56.2 & - & - & - & 67.2 & HSF-CW & $\begin{array}{l}\text { Modified river } \\
\text { water }\end{array}$ & Common reeds & 42 \\
\hline 64.0 & 68.0 & - & - & - & VSF-CW & $\begin{array}{l}\text { Secondary } \\
\text { sewage }\end{array}$ & P. purpureum & 14 \\
\hline 66.7 & - & - & 84.5 & - & HSF-CW & $\begin{array}{l}\text { Domestic } \\
\text { sewage }\end{array}$ & Reed grass & 43 \\
\hline 65.9 & - & - & - & 30.5 & HSF-CW & $\begin{array}{l}\text { Wastewater } \\
\text { from livestock }\end{array}$ & $\begin{array}{l}\text { Potamogeton } \\
\text { crispus }\end{array}$ & 44 \\
\hline 49.72 & - & - & - & 42.8 & VF-CW & $\begin{array}{l}\text { Secondary } \\
\text { wastewater }\end{array}$ & Sweet flag \\
\hline 42.0 & 85.0 & - & - & 39.0 & HSF-CW & $\begin{array}{l}\text { Domestic } \\
\text { wastewater }\end{array}$ & P. purpureum \\
\hline 41.3 & - & - & - & 65.9 & HSF-CW & $\begin{array}{l}\text { Secondary } \\
\text { Wastewater }\end{array}$ & $\begin{array}{l}\text { Potamogeton } \\
\text { crispus }\end{array}$ & 47 \\
\hline 66.2 & 88.1 & 57.5 & 66.6 & 62.3 & VSF-CW & POME FD & P. purpureum & This study \\
\hline
\end{tabular}

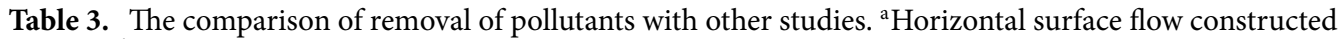
wetland. ${ }^{b}$ Vertical surface flow constructed wetland. ${ }^{c}$ Vertical flow constructed wetland.

tannin and lignin, colour, and ammonia were reduced from the effluent sample, as summarised in Table 2. All parameters met the river water quality except for COD. For future consideration, this study suggests an extended HRT to achieve a better efficacy in reducing the COD.

The designed CW treatment using $P$. purpureum showed a comparable removal with other studies, while some of the parameters showed better removal as shown in Table 3. A comparable COD removal efficiency of $66.2 \%$ was achieved, which was comparable to $66.7 \%{ }^{43}$ and $65.9 \%{ }^{44}$. For $\mathrm{NH}_{4}{ }^{+}-\mathrm{N}$ removal, this study recorded $62.3 \%$ removal from POME FD, which is within the range of other studies $\left(65.9 \%{ }^{48}\right.$ and $\left.67.2 \%{ }^{42}\right)$. Interestingly, the TSS showed a greater removal (85\%) as compared to a previous study $(68 \%)^{43}$.

Removal of trace elements in constructed wetland. The POME FD could be used as a source for nitrogen, phosphorus, potassium, magnesium, and calcium for plant growth ${ }^{48}$. The elements that were present in the POME FD are listed in Table 4. In phytoremediation studies, grass is the most common plant that has been used as it has high tolerance towards heavy metals. For this study, P. purpureum was used in the CW owing to its extensive fibrous roots (Fig. 4) that could reduce leaching and erosion ${ }^{49}$. All these characteristics give $P$. purpureum phytoremediation advantage where it can help to reduce the trace elements inside the POME FD. The phytoremediation concept managed to reduce the concentrations of potassium, silica, caesium, rubidium, sodium, copper, magnesium, calcium, strontium, and manganese in POME FD by $82.19 \%, 80.51 \%, 71.17 \%$, $66.07 \%, 58.46 \%, 59.27 \%, 56.81 \%, 35.80 \%, 35.57 \%$, and $20.81 \%$, respectively, as shown in Table 4 .

The concentration of silica in POME FD was quite high $(25.51 \pm 1.05 \mathrm{ppm})$ before treatment. However, after treatment with $\mathrm{CW}$, the concentration of silica was reduced by $80.51 \%$. This result shows the capability of $P$. purpureum to remediate silica by absorbing and immobilising it. Silica will be uptaken by the plant, and processed to form phytoliths or silica bodies which infill the cell walls and lumina of certain plant cells ${ }^{50}$. The uptake of silica by the plant improves its quality by showing increased chlorophyll content and plant growth ${ }^{51}$. On the other hand, the plant in the CW also shows a rapid growth in "Plant physiology" section. Based on this, it can be concluded that the silica uptake by the plant managed to increase the chlorophyll content and growth of $P$. purpureum while at the same time reduced the concentration of silica inside the POME FD. It has been proven that plants are capable to reduce and remediate caesium by $59.3 \%$ through accumulation at the dry shoots, which is similarly shown in this study with caesium removal of $71.17 \%$ by $P$. purpureum in the $\mathrm{CW}^{52}$. 


\begin{tabular}{|l|c|c|l|l|}
\hline Trace element & Influent $(\mathbf{p p m})$ & Effluent $(\mathbf{p p m})$ & Removal (\%) & Standard discharge limit by DOE (ppm) \\
\hline Potassium & $201.81 \pm 3.02$ & $35.94 \pm 1.01$ & 82.19 & - \\
\hline Silica & $25.51 \pm 1.05$ & $4.97 \pm 0.14$ & 80.51 & - \\
\hline Caesium & $0.111 \pm 0.001$ & $0.032 \pm 0.002$ & 71.17 & - \\
\hline Rubidium & $4.76 \pm 0.032$ & $1.62 \pm 0.12$ & 66.07 & - \\
\hline Sodium & $14.38 \pm 0.45$ & $5.97 \pm 0.63$ & 58.46 & - \\
\hline Copper & $0.033 \pm 0.0003$ & $0.013 \pm 0.001$ & 59.27 & 0.2 \\
\hline Magnesium & $318.25 \pm 5.01$ & $137.45 \pm 1.02$ & 56.81 & - \\
\hline Calcium & $70.32 \pm 0.87$ & $45.15 \pm 2.87$ & 35.80 & - \\
\hline Strontium & $0.30 \pm 0.01$ & $0.19 \pm 0.01$ & 35.57 & - \\
\hline Manganese & $0.042 \pm 0.001$ & $0.033 \pm 0.001$ & 20.81 & 0.2 \\
\hline
\end{tabular}

Table 4. The trace element concentrations in influent and effluent for wetland treatment.

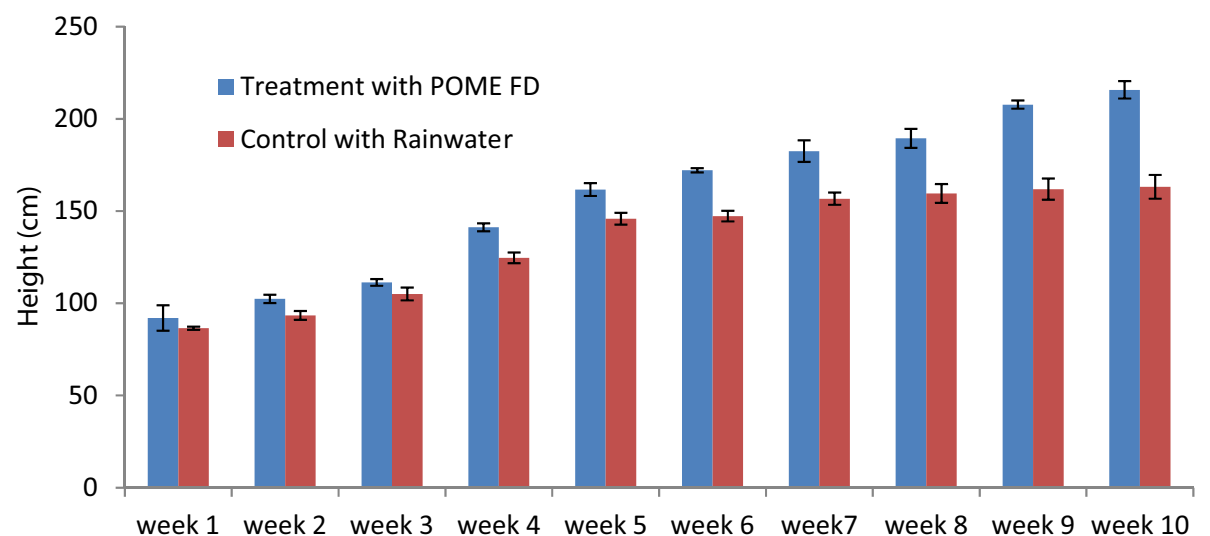

Figure 8. The growth of $P$. purpureum in the constructed wetland system for 75 days.

Plant physiology. The growth performance of $P$. purpureum is measured in term of height, of as shown in Fig. 8. The initial heights of $P$. purpureum were $92 \mathrm{~cm}$ and $86 \mathrm{~cm}$ for treatment with POME FD and control with rainwater, respectively. On the last day of experiment, the height of $P$. purpureum treated with POME FD increased by $135 \pm 12 \%$, but only $88 \pm 9 \%$ in control. This is due to the uptake of nutrient from the water sources ${ }^{53}$. A study ${ }^{54}$ reported that plant height increment of $61 \pm 2 \%$ can be observed when it was treated with POME FD. As mentioned in "Removal of trace elements in constructed wetland" section, silica increases the growth of the plant, while potassium functions as the major osmoticum of the plant cells which controls cellular expansion ${ }^{53}$.

Bacterial community analysis. The other component of wetlands such as microorganisms have been proven to help on the reduction of the pollutants or contaminants in a $\mathrm{CW}$, such as ammonium, nitrate, organic matters, industrial organics, and emerging organic contaminants/pollutants ${ }^{15-18}$. The submerged plant litter did affect the soil properties and microbial diversities in a $\mathrm{CW}^{55}$. As shown in Fig. 9, Proteobacteria yielded the highest percentage in the phylum, ranging from 37 to $70.7 \%$. Proteobacteria is one of the three most abundant soil bacteria phyla, and the most widespread and ubiquitous. These phyla are found dominant in wastewater treatment ${ }^{23,56}$. It was reported that Proteobacteria had a high resistance towards heavy metals ${ }^{57}$. The Proteobacteria and Firmicutes phyla can live together in harsh environments, and have been shown to have the potential to remove a broad-spectrum of heavy metals ${ }^{58}$. Proteobacteria are copiotrophic and root-associated bacteria that influence $\mathrm{NO}_{3}{ }^{-}-\mathrm{N}$ and $\mathrm{NH}_{4}{ }^{+}-\mathrm{N}$ in the soil ${ }^{45}$. Proteobacteria do not show a consistent change in depth ${ }^{59,60}$. Proteobacteria including Nitrosomonas, Nitrosococcus, and Nitrosospira have been reported as ammonia-oxidising bacteria $^{61}$.

Chloroflexi is a phylum of primarily gliding, filamentous bacteria possessing a wide diversity of metabolisms and ecological roles, but are best known as photoheterotrophs ${ }^{62}$. Chloroflexi percentage at the beginning of the system was low $(0.96 \%)$ but increased thereafter to $18.11 \%$. Wetland soils are characterised by high soil moisture, and this habitat may be suitable for some bacterial phyla such as Chloroflexi to grow ${ }^{63}$. Since it is photoheterotrophic, it cannot use $\mathrm{CO}_{2}$ as a carbon source, but use the organic compounds instead, thus helping in the removal of pollutants. Chloroflexi are aerobic and anaerobic thermophiles, filamentous anoxygenic phototrophs, and anaerobic organohalides ${ }^{64}$. Since this phylum is anaerobic, it can survive in the CW even though the system does not have aeration. 


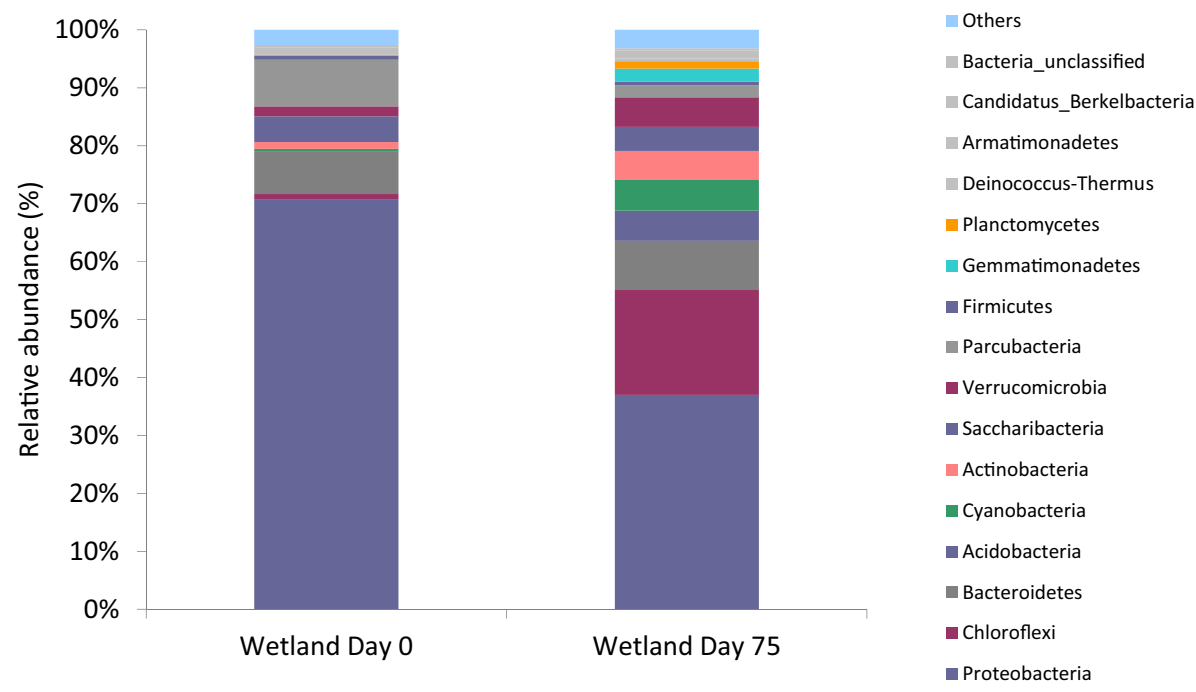

Figure 9. Relative abundance of the dominant phylogenetic groups at each sampling point during this study with relative abundance at the phyla level with $>0.002 \%$.

Acidobacteria in this study also increased from 0.14 to $5.2 \%$ which shows the capability of these phyla to survive and adapt in the CW condition. These phyla have a unique ability including the ability to use nitrite as a nitrogen source, which gives positive impacts to soil macro- and micronutrients, and these phyla can also express multiple active transporters.

Cyanobacteria are phyla that contain members that possess two photosystems that are coupled in series to perform oxygenic photosynthesis. Cyanobacteria occupy a privileged position among microorganisms because of their role in carbon and nitrogen cycles ${ }^{65}$. These phyla also showed an increment in abundancy in the CW after treatment for 102 days. The phyla increased from 0.39 to $5.29 \%$, which gives a clear indication that Cyanobacteria did involve in the pollutant reduction.

Based on Fig. 10, Anaerolineaceae, Cyanobacteria, Acidobacteria, and Nitrosomonadaceae were detected in the samples of POME FD and treated POME FD. These four genera showed an increment in the CW after the treatment of POME FD for 75 days. Given the fermentative metabolism-capability to consume carbohydrates and proteinaceous carbon sources under anaerobic conditions, Anaerolineaceae growth had increased from 0.67 to $13.21 \%$, signaling its participation in COD and ammonia removals ${ }^{66}$.

Cyanobacteria also showed an increment in the CW up to $93.9 \%$. In the beginning, it was only $0.3 \%$, but at the end of the system, it increased to $4.92 \%$. This also shows the effectiveness of this genus to grow in this condition, and aid in the removal of pollutants in the POME FD. Cyanobacteria may affect the abundance of several genera across several phyla, in which most are associated with nitrogen metabolism. For example, the increase in the abundance of Cyanobacteria under nitrogen addition may be due to its great demand for nitrogen. Cyanobacteria cells are composed of nitrogen, nitrate and ammonium, which are common sources of nitrogen for Cyanobacteria. Cyanobacteriaare facultative bacteria.

At the beginning of the experiment, Acidobacteria only showed $0.06 \%$ abundance, but after 102 days, the value increased to $2.44 \%$. This also shows the ability of this genus to grow in the $\mathrm{CW}$, which suggest its association in the removal of pollutants in the POME FD. Meanwhile, Nitrosomonadaceae, which belongs to $\beta$-proteobacteria, is also an ammonium-oxidising bacteria involved in the nitrification process ${ }^{67}$. This genus' increment from 0.07 to $1.1 \%$ provides strong proof that nitrification had occurred in the $\mathrm{CW}$ which led to the decrement of ammonia nitrogen and total nitrogen inside the POME FD.

\section{Conclusions}

1. The proposed system had successfully produced effluent that met the river quality standard for all parameters, except for COD. In this study, COD removal was $62.2 \%$, TSS by $88.1 \%$, tannin and lignin by $57.5 \%$, colour by $66.6 \%$, and ammonia nitrogen by $62.3 \%$.

2. The trace elements were substantially reduced; silica by $80.5 \%$, caesium by $71.2 \%$, rubidium by $66.1 \%$, strontium by $35.6 \%$, magnesium by $56.8 \%$, manganese by $20.8 \%$, and copper by $59.3 \%$.

3. The cultivated $P$. purpureum showed higher growth rate as compared to control by $16.4 \%$ with nutrients (macro-nutrients) uptake efficiency from the POME FD achieved at 54.6\% for nitrogen, 91.8\% for phosphorus, $75 \%$ for potassium, and $58.5 \%$ for sodium.

4. It is suggested that Anaerolineaceae, Cyanobacteria, Acidobacteria, and Nitrosomonadaceae were associated with the residual pollutant removal.

5. This study proposed a promising low-cost system that has remarkable implications for the quality of the treated effluent. 


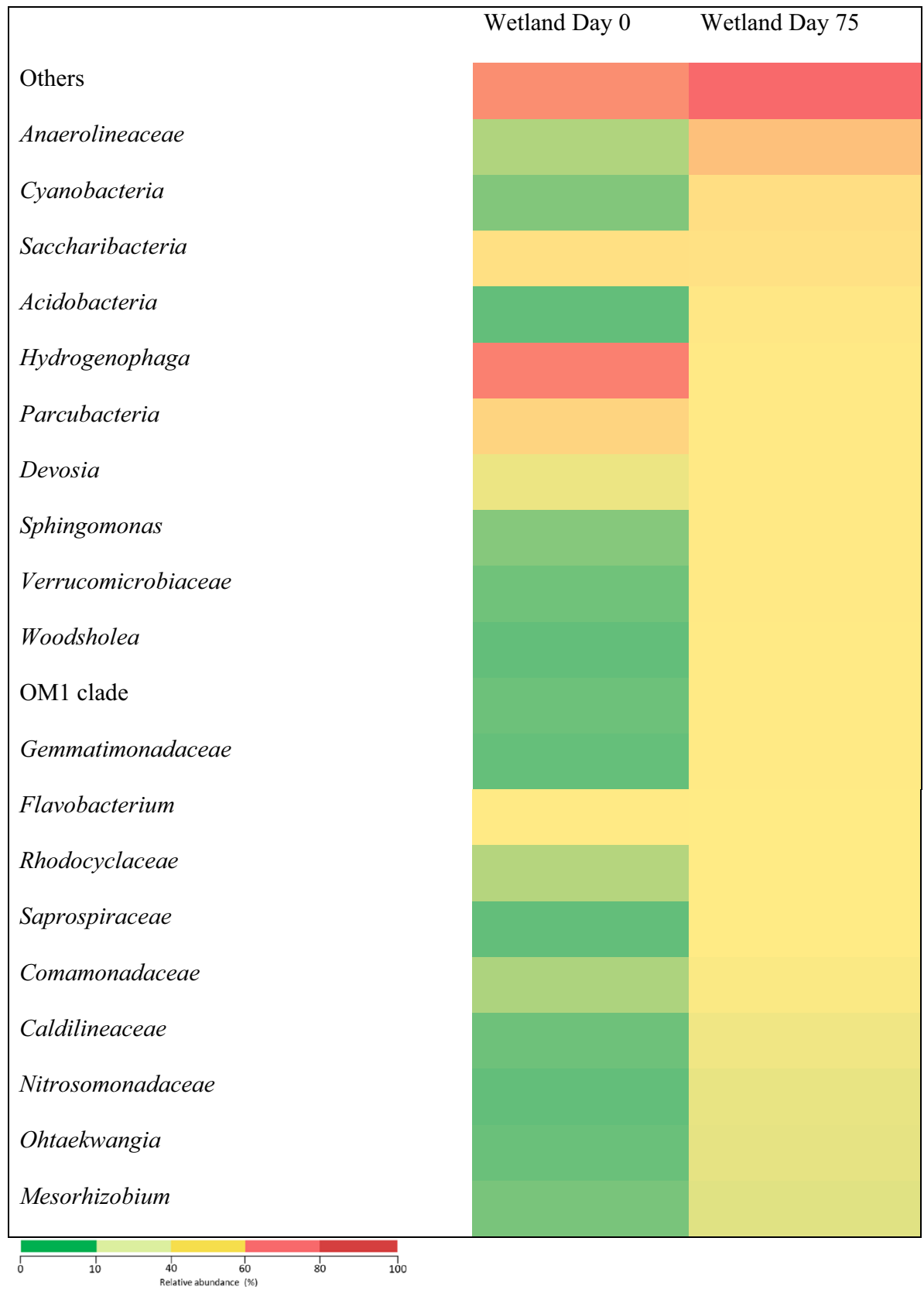

Figure 10. Heatmap of the relative abundance of genera and orders in the POME FD (day 0 ) and the treated POME FD (day 102).

Received: 30 September 2020; Accepted: 27 August 2021

Published online: 14 September 2021

\section{References}

1. Mahmod, S. S. et al. Potential utilisation of dark-fermented palm oil mill effluent in continuous production of biomethane by self-granulated mixed culture. Sci. Rep. 10, 1-12 (2020).

2. Gan, P. Y. \& Li, Z. D. Econometric study on Malaysias palm oil position in the world market to 2035. Renew. Sustain. Energy Rev. 39, 740-747 (2014).

3. Abdullah, N. \& Sulaiman, F. The oil palm wastes in malaysia. In Biomass now-sustainable growth and use, 75-93 (2013) https:// doi.org/10.5772/55302.

4. Chan, Y. J., Chong, M. F. \& Law, C. L. Biological treatment of anaerobically digested palm oil mill effluent (POME) using a lab-scale sequencing batch reactor (SBR). J. Environ. Manag. 91, 1738-1746 (2010).

5. Madaki, Y. S. \& Lau, S. Palm oil effluent (POME) from Malaysia palm oil mills: Waste or resource. Int. J. Sci. Environ. Technol. 2, $1138-1155$ (2013).

6. Rupani, P. F., Rajeev, P. S., Irahim, M. H. \& Esa, N. Review of current palm oil mill effluent (POME) treatment methods: Vermicomposting as a sustainable practice. World Appl. Sci. J. 11, 70-81 (2010). 
7. Singh, R. P., Ibrahim, M. H., Esa, N. \& Iliyana, M. S. Composting of waste from palm oil mill: A sustainable waste management practice. Rev. Environ. Sci. Biotechnol. 9, 331-344 (2010).

8. Ibrahim, I. et al. Reduction of residual pollutants from biologically treated palm oil mill effluent final discharge by steam activated bioadsorbent from oil palm biomass. J. Clean. Prod. 141, 122-127 (2017).

9. Othman, M. R. et al. Treatment of effluents from palm oil mill process to achieve river water quality for reuse as recycled water in a zero emission system. J. Clean. Prod. 67, 58-61 (2014).

10. Greipsson, S. Phytoremediation. Nat. Educ. Knowl. 3, 7 (2015).

11. Lone, M. I., He, Z., Stoffella, P. J. \& Yang, X. Phytoremediation of heavy metal polluted soils and water: Progresses and perspectives. J. Zhejiang Univ. Sci. B 9, 210-220 (2008).

12. Wu, H. et al. A review on the sustainability of constructed wetlands for wastewater treatment: Design and operation. Bioresour. Technol. 175, 594-601 (2015).

13. Chen, Y., Wen, Y., Zhou, Q. \& Vymazal, J. Effects of plant biomass on nitrogen transformation in subsurface-batch constructed wetlands: A stable isotope and mass balance assessment. Water Res. 63, 158-167 (2014).

14. Klomjek, P. Swine wastewater treatment using vertical subsurface flow constructed wetland planted with Napier grass. Sustain. Environ. Res. 26, 217-223 (2016).

15. Kaseva, M. E. Performance of a sub-surface flow constructed wetland in polishing pre-treated wastewater-A tropical case study. Water Res. 38, 681-687 (2004).

16. Zhang, D. et al. Application of constructed wetlands for wastewater treatment in tropical and subtropical regions (2000-2013). J. Environ. Sci. 30, 30-46 (2015).

17. Lin, Y., Yin, J., Wang, J. \& Tian, W. Performance and microbial community in hybrid anaerobic baffled reactor-constructed wetland for nitrobenzene wastewater. Bioresour. Technol. 118, 128-135 (2012).

18. Al-baldawi, I. A., Rozaimah, S. \& Abdullah, S. Preliminary test of hydrocarbon exposure on Azolla pinnata in phytoremediation process. Int. Conf. Environ. Energy Biotechnol. IPCBEE 33, 244-247 (2012).

19. Fernandes, J. P. et al. Microbial community dynamics associated with veterinary antibiotics removal in constructed wetlands microcosms. Bioresour. Technol. 182, 26-33 (2015).

20. Weber, K. P. \& Gagnon, V. Microbiology in treatment wetlands. Sust Sanit Pr. 18, 25-30 (2014).

21. Ibekwe, A. M., Ma, J. \& Murinda, S. E. Bacterial community composition and structure in an Urban River impacted by different pollutant sources. Sci. Total Environ. 566, 1176-1185 (2016).

22. Lloyd, J. R., Klessa, D. A., Parry, D. L., Buck, P. \& Brown, N. L. Stimulation of microbial sulphate reduction in a constructed wetland: Microbiological and geochemical analysis. Water Res. 38, 1822-1830 (2004).

23. Coban, O. et al. Nitrogen transforming community in a horizontal subsurface-flow constructed wetland. Water Res. 74, 203-212 (2015).

24. Zhang, X. et al. Simultaneous improvement of waste gas purification and nitrogen removal using a novel aerated vertical flow constructed wetland. Water Res. 130, 79-87 (2018).

25. Zhou, X., Wang, X., Zhang, H. \& Wu, H. Enhanced nitrogen removal of low $\mathrm{C} / \mathrm{N}$ domestic wastewater using a biochar-amended aerated vertical flow constructed wetland. Bioresour. Technol. 241, 269-275 (2017).

26. Truu, J., Truu, M., Espenberg, M., Nõlvak, H. \& Juhanson, J. Phytoremediation and plant-assisted bioremediation in soil and treatment wetlands: A review. Open Biotechnol. J. 9, 85-92 (2015).

27. Vymazal, J. Constructed wetlands for wastewater treatment in the Czech Republic the first 5 years experience. Water Sci. Technol. 34, 159-164 (1996).

28. Vymazal, J. \& Kröpfelová, L. Plants Used in Constructed Wetlands with Horizontal Subsurface Flow: A Review Vol. 14 (Springer, 2008).

29. Su, J., Yeh, K. \& Tseng, P. A strain of Pseudomonas sp. isolated from piggery wastewater treatment systems with heterotrophic nitrification capability in Taiwan. Curr. Microbiol. 53, 77-81 (2006).

30. Kalyani, D. C., Patil, P. S., Jadhav, J. P. \& Govindwar, S. P. Biodegradation of reactive textile dye Red BLI by an isolated bacterium Pseudomonas sp. SUK1. Bioresour. Technol. 99, 4635-4641 (2008).

31. Jayashree, R., Nithya, S. E., Prasanna, P. R. \& Krishnaraju, M. Biodegradation capability of bacterial species isolated from oil contaminated soil. J. Acad. Ind. Res. 1, 127-135 (2012).

32. Abdirahman Elmi, H. S. Colour and COD removal from palm oil mill effluent (POME) using Pseudomonas aeruginosa strain NCIM 5223 in microbial fuel cell. Int. J. Waste Resour. 05, 3-5 (2015).

33. Sonune, N. A. \& Garode, A. M. Bioremediation potential of bacterial isolates for municipal wastewater treatment. Curr. World Environ. 10, 619-625 (2015).

34. Dhulap, V. P. \& Patil, S. S. Removal of pollutants from sewage through constructed wetland using Pennisetum purpureium. Eur. Educ. Res. J. 2, 543-558 (2014).

35. Mohammed, R. R. \& Chong, M. F. Treatment and decolorization of biologically treated palm oil mill effluent (POME) using banana peel as novel biosorbent. J. Environ. Manag. 132, 237-249 (2014).

36. Grismer, M. E. \& Shepherd, H. L. Plants in constructed wetlands help to treat agricultural processing wastewater. Calif. Agric. 65, 73-79 (2011).

37. Masbough, A., Frankowski, K., Hall, K. J. \& Duff, S. J. B. The effectiveness of constructed wetland for treatment of woodwaste leachate. Calif. Agric. 65, 73-79 (2011).

38. Kang, W. et al. Assessment of low concentration wastewater treatment operations with dewatered alum sludge-based sequencing batch constructed wetland system. Sci. Rep. 7, 1-7 (2017).

39. Sikora, F. J., Tong, Z., Behrends, L. L., Steinberg, S. L. \& Coonrod, H. S. Ammonium removal in constructed wetlands with recirculating subsurface flow: Removal rates and mechanisms. Water Sci. Technol. 32, 193-202 (1995).

40. Ogheneruemu, A., Oluchi, E. \& Sikoki, F. D. Assessing and modelling the efficacy of Lemna paucicostata for the phytoremediation of petroleum hydrocarbons in crude oil-contaminated wetlands. Sci. Rep. 10, 1-9 (2020).

41. Canfield, D. E., Glazer, A. N. \& Falkowski, P. G. The evolution and future of earth's nitrogen cycle. Science 330, 192-196 (2010).

42. Ge, Z. et al. Natural pyrite to enhance simultaneous long-term nitrogen and phosphorus removal in constructed wetland: Three years of pilot study. Water Res. 148, 153-161 (2019).

43. Júnior, V. E., De Matos, A. T., Monaco, P. A., De Campos, L. C. \& Borges, A. C. Efficiency of constructed wetland systems cultivated with black oats treatment of domestic sewage. Acta Sci. Technol. 34, 391-398 (2012).

44. Wang, Y., Wang, J., Zhao, X., Song, X. \& Gong, J. The inhibition and adaptability of four wetland plant species to high concentration of ammonia wastewater and nitrogen removal efficiency in constructed wetlands. Bioresour. Technol. 202, 198-205 (2016).

45. Zhang, X. et al. A novel aerated surface flow constructed wetland using exhaust gas from biological wastewater treatment: Performance and mechanisms. Bioresour. Technol. 250, 94-101 (2018).

46. Tilak, A. S., Wani, S. P., Patil, M. D. \& Datta, A. Evaluating wastewater treatment efficiency of two field scale subsurface flow constructed wetlands. Curr. Sci. 110, 1764-1772 (2016)

47. Zhang, J. et al. Enhancement of surface flow constructed wetlands performance at low temperature through seasonal plant collocation. Bioresour. Technol. 224, 222-228 (2017).

48. Muhrizal, S., Shamshuddin, J., Fauziah, I. \& Husni, M. A. H. Changes in iron-poor acid sulfate soil upon submergence. Geoderma 131, 110-122 (2006). 
49. Jadia, C. D. \& Fulekar, M. H. Phytotoxicity and remediation of heavy metals by fibrous root grass (sorghum). J. Appl. Biosci. 10, 491-499 (2008).

50. Currie, H. A. \& Perry, C. C. Silica in plants: Biological, biochemical and chemical studies. Ann. Bot. 100, 1383-1389 (2007).

51. Korndörfer, G. H. \& Lepsch, I. Effect of silicon on plant growth and crop yield. Stud. Plant Sci. 8, 133-147 (2001).

52. Anamika, S., Eapen, S. \& Fulekar, M. H. Phytoremediation of cadmium, lead and zinc by Brassica juncea L. Czern and Coss. J. Appl. Biosci. 13, 726-736 (2009).

53. Prinzenberg, A. E., Barbier, H., Salt, D. E., Stich, B. \& Reymond, M. Relationships between growth, growth response to nutrient supply, and ion content using a recombinant inbred line population in Arabidopsis. Plant Physiol. 154, 1361-1371 (2010).

54. Osman, N. A., Ujang, F. A., Roslan, A. M., Ibrahim, M. F. \& Hassan, M. A. The effect of palm oil mill effluent final discharge on the characteristics of Pennisetum purpureum. Sci. Rep. 10, 1-10 (2020).

55. Ping, Y., Pan, X., Li, W., Wang, J. \& Cui, L. The soil bacterial and fungal diversity were determined by the stoichiometric ratios of litter inputs: Evidence from a constructed wetland. Sci. Rep. 9, 1-7 (2019).

56. Ma, C., Ming, H., Lin, C., Naidu, R. \& Bolan, N. Phytoextraction of heavy metal from tailing waste using Napier grass. CATENA 136, 74-83 (2016).

57. Feris, K. et al. Differences in hyporheic-zone microbial community structure along a heavy-metal contamination gradient. Appl. Environ. Microbiol. 69, 5563-5573 (2003).

58. Karelová, E., Harichová, J., Stojnev, T., Pangallo, D. \& Ferianc, P. The isolation of heavy-metal resistant culturable bacteria and resistance determinants from a heavy-metal-contaminated site. Biologia 66, 18-26 (2011).

59. Eilers, K. G., Debenport, S., Anderson, S. \& Fierer, N. Soil biology \& biochemistry digging deeper to find unique microbial communities : The strong effect of depth on the structure of bacterial and archaeal communities in soil. Soil Biol. Biochem. 50, 58-65 (2012).

60. Will, C. et al. Horizon-specific bacterial community composition of German grassland soils, as revealed by pyrosequencing-based analysis of 16S rRNA genes. Appl. Environ. Microbiol. 76, 6751-6759 (2010).

61. Luo, X. et al. Structure of the Legionella virulence factor, SidC reveals a unique PI (4) P-specific binding domain essential for its targeting to the bacterial phagosome. PLoS Pathog. 11, e1004965 (2015).

62. Van Gemerden, H. \& Jordi, M. Ecology of phototrophic sulfur bacteria. In Anoxygenic Photosynthetic Bacteria 49-85 (Springer, 1995) https://doi.org/10.1007/978-1-4020-6863-8_19.

63. Sui, X. et al. Land use change effects on diversity of soil bacterial, Acidobacterial and fungal communities in wetlands of the Sanjiang Plain, northeastern China. Sci. Rep. 9, 1-14 (2019).

64. Krzmarzick, M. J. et al. Natural niche for organohalide-respiring Chloroflexi. Appl. Environ. Microbiol. 78, 393-401 (2012).

65. Whitton, B. A. Ecology of Cyanobacteria II: Their Diversity in Space and Time (Springer, 2012) https://doi.org/10.1007/ 978-94-007-3855-3.

66. Sekiguchi, Y. et al. Tepianaerobacter syntrophicus gen. nov., sp. nov., an anaerobic, moderately thermophilic, syntrophic alcoholand lactate-degrading bacterium isolated from thermophilic digested sludges. Int. J. Syst. Evol. Microbiol. 56, 1621-1629 (2006).

67. Xu, D., Liu, S., Chen, Q. \& Ni, J. Microbial community compositions in different functional zones of Carrousel oxidation ditch system for domestic wastewater treatment. AMB Express 7, 40 (2017).

\section{Acknowledgements}

The authors would like to thank Universiti Putra Malaysia for the technical and financial assistance in this study (Matching grant No. GP-IPM/2016/9510900). APC was funded by Research Management Centre (RMC), Universiti Putra Malaysia (UPM) Malaysia. The authors would also like to acknowledge the Japan International Cooperation Agency (JICA) through the SATREPS program for the training of the first author.

\section{Author contributions}

(1) F.A.U. conceived the presented idea, which was further elaborated by A.M.R. and M.G. F.A.U. wrote the manuscript with support from M.A.A.F. (2) A.M.R., M.A.H, J.I. and M.I.E.H. helped supervise the project and verified the analytical methods. (3) F.A.U. had carried out the experiment with support from N.A.O. and A.N.

\section{Competing interests}

The authors declare no competing interests.

\section{Additional information}

Correspondence and requests for materials should be addressed to A.M.R.

Reprints and permissions information is available at www.nature.com/reprints.

Publisher's note Springer Nature remains neutral with regard to jurisdictional claims in published maps and institutional affiliations.

Open Access This article is licensed under a Creative Commons Attribution 4.0 International

License, which permits use, sharing, adaptation, distribution and reproduction in any medium or format, as long as you give appropriate credit to the original author(s) and the source, provide a link to the Creative Commons licence, and indicate if changes were made. The images or other third party material in this article are included in the article's Creative Commons licence, unless indicated otherwise in a credit line to the material. If material is not included in the article's Creative Commons licence and your intended use is not permitted by statutory regulation or exceeds the permitted use, you will need to obtain permission directly from the copyright holder. To view a copy of this licence, visit http://creativecommons.org/licenses/by/4.0/.

(C) The Author(s) 2021 